https://doi.org/10.15407/ujpe63.6.557

M. ALIZADEH, V.YA. DEGODA

Taras Shevchenko National University of Kyiv

(64, Volodymyrs'ka Str., 01601 Kyiv, Ukraine; e-mail: trefoilsymbol@gmail.com,

degoda@univ.kiev.ua)

\title{
THE SPECTRA OF X-RAY AND PHOTOLUMINESCENCE OF HIGH-RESISTANCE CRYSTALS OF ZnSe ${ }^{1}$
}

\begin{abstract}
The luminescence spectra of high-resistance ZnSe crystals consist of two main bands with maxima at $630 \mathrm{~nm}(1.92 \mathrm{eV})$ and $970 \mathrm{~nm}(1.28 \mathrm{eV})$. The planned comparison has been carried out between the spectra of X-ray luminescence and photoluminescence of $Z n S e$ among themselves in the spectral region from 400 to $1200 \mathrm{~nm}$ at different excitation intensities and different temperatures $(8,85,295$, and 420 K). It is found that the forms of luminescence bands do not depend on the excitation intensities. The band form with a maximum at $970 \mathrm{~nm}$ also does not depend on the excitation type, and the band at $630 \mathrm{~nm}$ differs slightly under the X-ray and $U V$ excitations. The temperature dependences of the spectral positions of bands' maxima and their half-widths are analyzed. A conclusion is drawn that the 970-nm emission band is elementary. A short-wavelength shift of the spectral maximum of the 630-nm band with increasing the temperature makes it possible to conclude that this luminescence band is non-elementary. This correlates with the previously discovered feature of this band related to the realization of two recombination mechanisms (electron and hole) at this luminescent center.
\end{abstract}

Keywords: spectra of X-ray luminescence, spectra of photoluminescence, center of recombination, temperature dependences of the spectral position of the maximum and half-width of the band, zinc selenide.

\section{Introduction}

Zinc selenide (ZnSe) belongs to the most promising wide-band gap materials of the $\mathrm{A}^{\mathrm{II}} \mathrm{B}^{\mathrm{VI}}$ type and is used widely in the creation of devices of shortwave semiconductor electronics and information display systems, as well as in the manufacturing of lenses and windows for IR radiation. This material is very promising for indirect ionizing radiation detectors $(\gamma-$ radiation scintillators) [1] and for the direct conversion of the energy of high-energy radiation into an electric current (semiconductor detectors) [2]. This became possible after the development of technologies for growing high-quality crystals with low concentrations of uncontrolled impurities and a high resistivity of $10^{12}-10^{14} \mathrm{ohm} \cdot \mathrm{cm}$. A large average atomic number $(Z=32)$ and a large band gap width $(2.7 \mathrm{eV}$ at $300 \mathrm{~K})$ make ZnSe a perspective material for creating $\mathrm{X}$-ray detectors that do not need cooling [3]. It is experimentally proven that when recording an ionizing radiation, in particular, X-ray radiation, the kinetics

(C) M. ALIZADEH, V.YA. DEGODA, 2018

ISSN 2071-0194. Ukr. J. Phys. 2018. Vol. 63, No. 6 of the ZnSe conductivity and luminescence appreciably differs from that under the UV excitation. This work is aimed to carry out a complex experimental study of the ZnSe luminescence under X-ray and UV excitations at various intensities and temperatures.

\section{Experimental Technique and Details}

The luminescence of ZnSe single crystals was studied under the excitation by X-ray and UV quanta. The specially unalloyed ZnSe crystals grown from a prepurified batch were investigated. We obtained the crystals with a minimum impurity concentration and a maximum resistivity $\left(\rho \geq 10^{12} \Omega \mathrm{cm}\right)$. The concentration of free electrons in such crystals is $10^{2}-$ $10^{4} \mathrm{~cm}^{-3}$.

During the luminescence study, the sample was placed in a cryostat allowing us to use temperatures of $8,85,295$, and $420 \mathrm{~K}$. The X-ray excitation

1 The paper was presented at the XXIII Galyna Puchkovska International School-Seminar "Spectroscopy of Molecules and Crystals". 


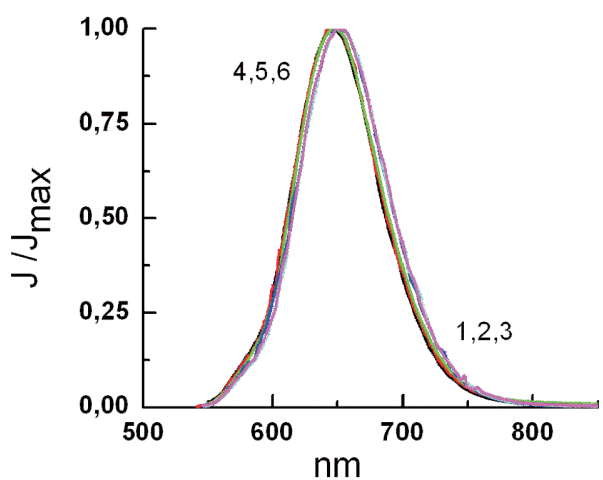

$a$

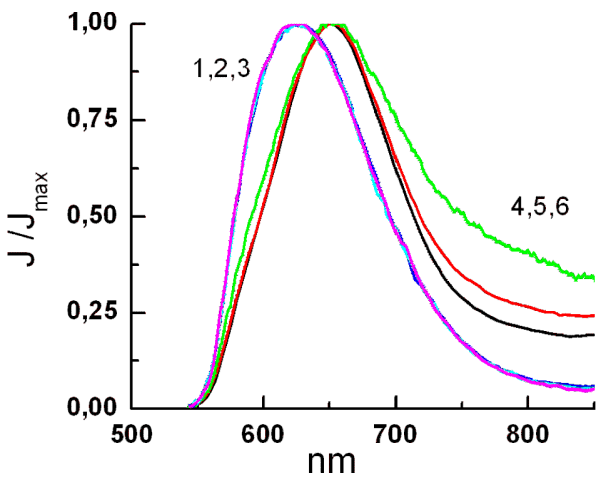

$c$

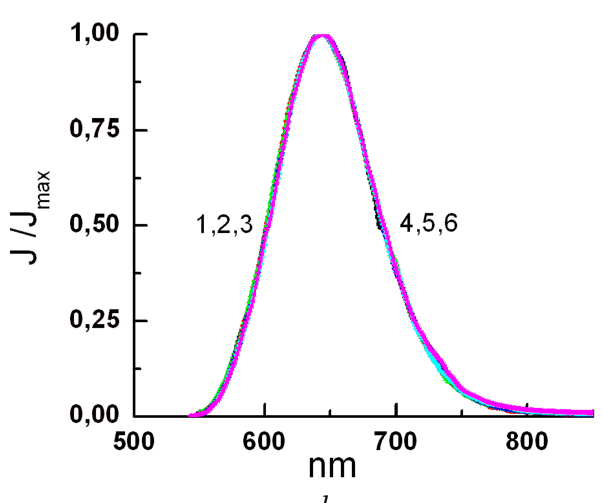

$b$

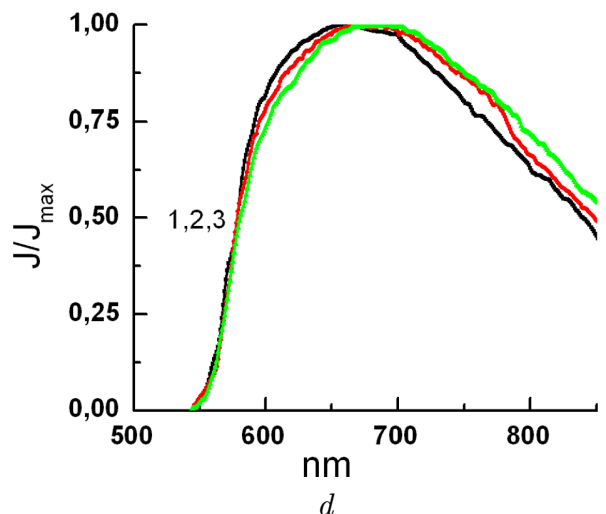

$d$

Fig. 1. Normalized spectra of XRL (1-3) and PL (4-6) for a ZnSe sample with the 630-nm band at temperatures of $8 \mathrm{~K}(a), 85 \mathrm{~K}(b), 295 \mathrm{~K}(c)$, and $420 \mathrm{~K}(d)$ for various X-ray excitation intensities: $I_{\mathrm{X} \text {-tube }}=5 \mathrm{~mA}(1), 15 \mathrm{~mA}(2), 25 \mathrm{~mA}$ (3), and UV excitations: $I_{7 \mathrm{LED}}=40 \mathrm{~mA}$ (4), $90 \mathrm{~mA}(5), 180 \mathrm{~mA}(6)$

was performed by the integrated radiation of an $\mathrm{X}$ ray tube $\mathrm{BXB} 7\left(\mathrm{Re}, 20 \mathrm{kV}, I_{\mathrm{X}-\text { tube }}=5 \div 25 \mathrm{~mA}\right)$ through a beryllium window of a cryostat. The distance from the anode of an X-ray tube to the sample was $120 \mathrm{~mm}$. For the photoexcitation, 7 identical ultraviolet UF-301 light emitting diodes (395 nm wavelength, i.e., less than the ZnSe band gap, total current $I_{7 \mathrm{LED}}=30 \div 180 \mathrm{~mA}$ ) were used. They simultaneously irradiated the sample via the quartz window of a cryostat. The radiation intensity of both the X-ray tube and the LEDs is proportional to the magnitude of the supplied current, and the radiation spectrum form remains unchanged. The luminescence spectra were recorded using photoelectric multipliers FEU-106 and FEU-83 (in the cooling regime) through an MDR-2 monochromator. All spectra of X-ray luminescence (XRL) and photoluminescence (PL) were adjusted taking the spectral sensitivity of the recording system into account. Moreover, when the spectra were transferred from the wavelength scale (nm) onto the energy scale of quanta $(\mathrm{eV})$, the spectra were corrected to the spectral radiation density.

\section{Luminescence Spectra}

The spectra of XRL and PL for 6 high-resistance ZnSe samples from different degenerate bulbs at 85 and $295 \mathrm{~K}$ consist of two main luminescence bands with maxima at $630 \mathrm{~nm}(1.92 \mathrm{eV})$ and $970 \mathrm{~nm}$ $(1.28 \mathrm{eV})$. According to [4-7], the band with a maximum at $630 \mathrm{~nm}$ is due to a complex center including a zinc vacancy. A band with a maximum at $970 \mathrm{~nm}$ is due to a complex center with a vacancy of selenium or an admixture of copper [8,9]. It is worth to note that, firstly, the intensity ratio of these bands differs for various crystals, which indicates the independence of the concentrations of luminescent centers that cause these bands. Second, the spectral positions of the maximum of the $630-\mathrm{nm}$ band differ 
for various samples and range from 615 to $650 \mathrm{~nm}$, whereas the $970-\mathrm{nm}$ bands are identical. Third, these two luminescence bands are observed in the phosphorescence emission spectra and the thermally stimulated luminescence, which demonstrates the recombination character of the luminescence at these centers. Fourth, although the generation mechanisms of electronic excitations under the X-ray and UVexcitations significantly differ, the ratios of intensities of these luminescence bands practically coincide in each of high-resistance ZnSe crystals. For one of the samples of this series, the spectroscopic studies were carried out at different intensities of the X-and UV-excitations and various temperatures (8, 85, 295, and $420 \mathrm{~K}$ ). The obtained normalized spectra of XRL and PL in the range from 500 to $1200 \mathrm{~nm}$ at different temperatures and various excitation intensity levels are shown in Fig. 1 for the $630-\mathrm{nm}$ band. Similar normalized spectra for the $970 \mathrm{~nm}$ band are shown in Fig. 2. At high temperatures $(420 \mathrm{~K})$, due to the temperature quenching of the luminescence, the intensity of XRL was so weak that it was impossible to reliably register the XRL spectrum even at the maximum X-ray excitation intensity. The PL spectrum at this temperature includes only the $630-\mathrm{nm}$ band, and the band at $970 \mathrm{~nm}$ is not observed clearly against the background of the long-wave wing. It should be noted that when the sensitivity of recording system was increased by two orders of magnitude in the spectral range from 400 to $550 \mathrm{~nm}$, neither the edge luminescence nor the luminescence of donor-acceptor pairs (DAP) at $8 \mathrm{~K}$ could be detected, when this emission is the brightest in $\mathrm{ZnSe}$.

It is seen that the normalized spectra of XRL and $\mathrm{PL}$ at different excitation intensities practically coincide, but differ somewhat under the X-ray and UV excitations. At the same time, the intensities of both $\mathrm{X}$-ray and UV excitations were changed by almost an order of magnitude. Therefore, the normalized XRL and PL spectra can be averaged among themselves and determine the spectral parameters of luminescence bands for averaged spectra.

\section{Spectral Parameters of Luminescence Bands}

In all $A^{\mathrm{II}} B^{\mathrm{VI}}$ semiconductors, as the temperature increases, an almost linear decrease in the width of the band gap is observed, i.e., the levels of the conduction
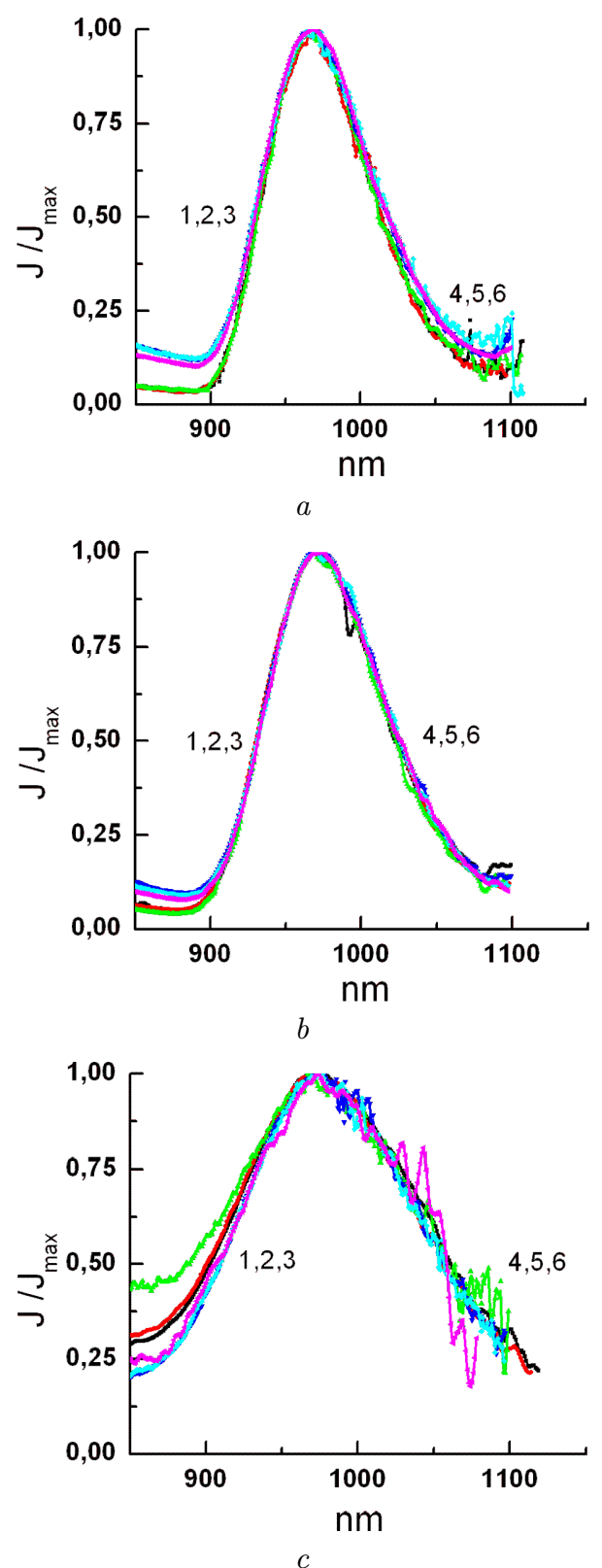

Fig. 2. Normalized spectra of XRL (1-3) and PL $(4-6)$ in a ZnSe sample of the 970-nm band at temperatures of $8 \mathrm{~K}$ (a), $85 \mathrm{~K}(b)$, and $295 \mathrm{~K}(c)$ for various X-ray excitation intensities: $I_{\mathrm{X}-\text { tube }}=5 \mathrm{~mA}(1), 15 \mathrm{~mA}(2)$, and $25 \mathrm{~mA}$ (3), and for the UV excitation: $I_{7 \mathrm{LED}}=40 \mathrm{~mA}(4), 90 \mathrm{~mA}(5)$, and $180 \mathrm{~mA}(6)$

and valence bands approach one another, and the energy intervals between the lower conduction band and the upper valence band decrease. Accordingly, this also affects the positions of the energy levels of local 

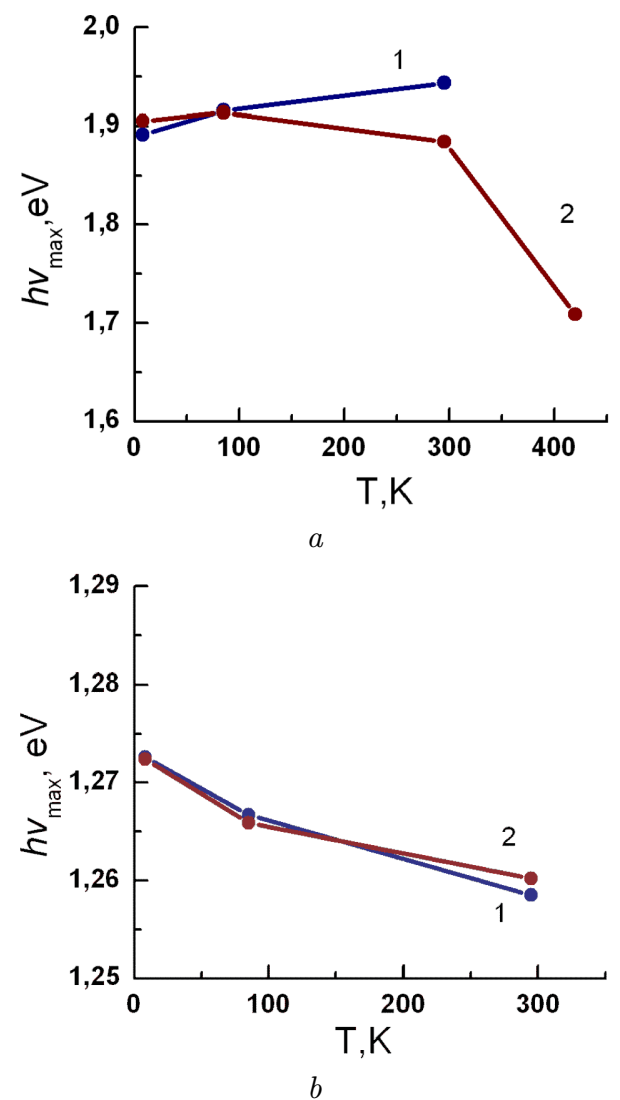

Fig. 3. Spectral positions of the luminescence band with maxima at $630 \mathrm{~nm}(a)$ and $970 \mathrm{~nm}$ (b) under X-ray (1) and UV (2) excitations of a $\mathrm{ZnSe}$ sample as a function of the temperature

centers in the band gap, including the luminescence centers $[10,11]$. This causes a decrease in the energy distance between the excited and ground levels of a recombination center of luminescence. Thus, as the temperature increases, a long-wave shift of the luminescence band maximum should occur. The corresponding dependences of spectral maxima of the 630and 970-nm bands for the X-ray and UV excitations are shown in Fig. 3.

The spectral position of the $630-\mathrm{nm}$ band under the UV excitation decreases monotonically with increasing the temperature and increases monotonically under the X-ray excitation. This demonstrates that this band consists of at least two close bands with different dependences of their intensity on the temperature. This can happen if, under the X-ray excitation, the contribution of a shorter-wave component to the total intensity of the band increases with the temper-

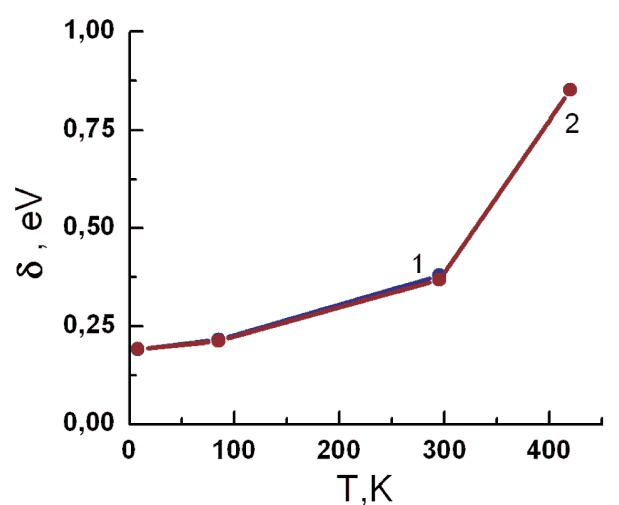

$a$

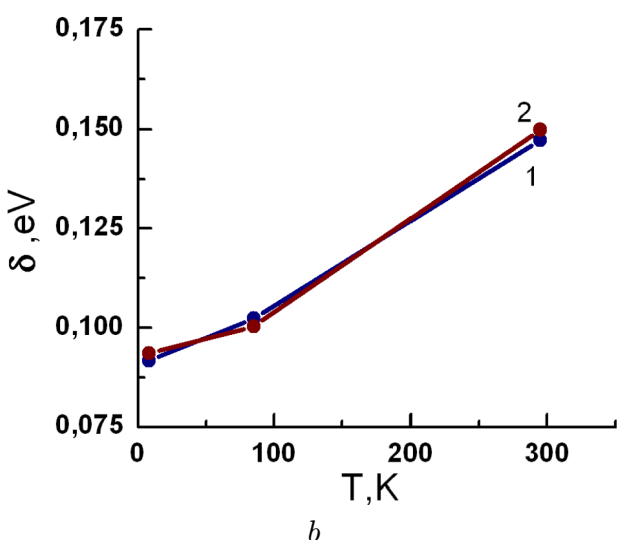

Fig. 4. Temperature dependences of the half-widths of the 630-nm (a) and 970-nm (b) bands for X-ray (1) and UV excitations (2) of a ZnSe crystal

ature, even though the spectral positions of maxima of each elementary band will be slightly shifted to the long-wavelength region. We should mind that the XRL intensity consists of two components: scintillation and recombination (and, as a rule, the scintillation emission intensity is several times more intense than for the recombination), and PL includes only the recombination luminescence. In addition, for the 970-nm band, the position of spectral maximum decreases monotonically both for XRL and PL, as the temperature increases. Moreover, in the temperature range of a linear decrease in the width of the band gap $(100-300 \mathrm{~K})$, an almost proportionality is observed between the maximum of the $970-\mathrm{nm}$ band, since the values of $\frac{\partial E_{g} / \partial T}{E_{g}} \approx 2.9 \times 10^{-4} \mathrm{~K}^{-1}$ and $\frac{\partial h \nu_{\max } / \partial T}{h \nu_{\max }} \approx 3.1 \times 10^{-4} \mathrm{~K}^{-1}$ are very close. For the impurity luminescence centers in crystals [10,11], the half-widths of luminescence bands should increase

ISSN 2071-0194. Ukr. J. Phys. 2018. Vol. 63, No. 6 
monotonically with the temperature. This is caused by an increase in the population of vibrational levels of the excited electronic state of luminescence centers with the temperature. Fig. 4 shows the temperature dependences of the half-widths $(\delta)$ of the averaged 630 - and $970-\mathrm{nm}$ bands under the X-ray and UV excitations.

It can be seen that the half-widths of both bands practically coincide under the X-ray and UV excitations at all temperatures. Thus, the monotonically increasing temperature dependences of the half-widths of the luminescence bands indicate the applicability of the configuration model of luminescence center to the luminescence center in ZnSe crystals. Although the half-widths of different luminescence bands, which are caused by the frequencies of local center oscillations, should differ from each other, we see that the halfwidth of the $630-\mathrm{nm}$ band is significantly larger than the half-width of the spectral band with the maximum at $970 \mathrm{~nm}$ at all temperatures. The photoconductivity studies in ZnSe crystals [12,13] showed that the main mechanism of recombination in the photoexcitation is the electron one (recombination of free electrons with localized holes at the centers of luminescence). However, by comparing i) the intensities of stationary XRL bands at 630 and $970 \mathrm{~nm}$ and the $\mathrm{X}$-ray conductivity with ii) the phosphorescence intensities (630 and $970 \mathrm{~nm}$ ) and the conductivity relaxation current, and iii) the intensities of the thermally stimulated luminescence (630 and $970 \mathrm{~nm}$ ) and the thermally stimulated conductivity current [14], we found that both recombination mechanisms (electron and hole) are realized at the luminescence center that causes the $630-\mathrm{nm}$ band, while only the electron recombination mechanism occurs on the luminescence center that causes the $970-\mathrm{nm}$ band. The obtained evidence of aa non-elementary nature of the $630-\mathrm{nm}$ band correlates well with this fact [15].

\section{Conclusions}

A comparison of the X-ray luminescence spectra of various high-resistance $\mathrm{ZnSe}$ crystals shows that they consist of two intense bands with maxima at $630 \mathrm{~nm}$ $(1.92 \mathrm{eV})$ and $970 \mathrm{~nm}(1.28 \mathrm{eV})$, but the intensity ratio of these bands differ in various crystals. The comparison of bands' forms at different intensities of the X-ray and UV excitations at temperatures 8, 85, 295, and $420 \mathrm{~K}$ gives the independence of bands' forms of the excitation intensity, and for the $970 \mathrm{~nm}$ band of the excitation type, as well. There are differences for a wide band of $630 \mathrm{~nm}$ under the X-ray and UV excitations. This difference is seen in the temperature dependences of the spectral position of the band maximum, which in XRL is shifted to the short-wave side, as the temperature of the crystal increases. Considering also the half-widths of the bands, an assumption is made about a non-elementary nature of the $630-\mathrm{nm}$ emission band. This assumption correlates with the fact that both mechanisms of recombination (electron and hole) are realized at this luminescence center.

1. V. Ryzhikov, N. Starzhinskiy, K. Katrunov, L. Gal'chinetskii. Absolute light yield of $\mathrm{ZnSe}(\mathrm{Te})$ and $\mathrm{ZnSe}(\mathrm{Te}, \mathrm{O})$. Functional Materials 9 (1), 135 (2002).

2. A.O. Sofiienko, V.Ya. Degoda. X-ray induced conductivity of $\mathrm{ZnSe}$ sensors at high temperatures. Radiation Measurements 47 (1), 27 (2012).

3. M.S. Brodin, V.Ya. Degoda, B.V. Kozhushko, A.O. Sofiienko, V.T. Vesna. Monocrystalline $\mathrm{ZnSe}$ as an ionising radiation detector operated over a wide temperature range. Radiation Measurements 65, 36 (2014).

4. V.D. Ryzhikov et al. New semiconductor scintillators $\mathrm{ZnSe}(\mathrm{Te}, \mathrm{O})$ and integrated radiation detectors based thereon. IEEE Trans. Nucl. Sci. 48 (1), 356 (2001).

5. V.M. Koshkin, A.Ya. Dulfan, V.D. Ryzhikov et al. Thermodynamics of isovalent tellurium substitution for selenium in ZnSe semiconductors. J. Functional materials $\mathbf{8}$ (4), 708 (2001).

6. G. Watkins. Defects of Lattice in Compounds $\mathrm{A}_{2} \mathrm{~B}_{6}$. In: Point Defects of Lattice (Mir, 1979), p. 1150 (in Russian).

7. L.V. Atroschenko, L.P. Gal'chinetskii, S.N. Galkin et al. Structure defects and phase transition in tellurium-doped ZnSe crystals. J. Cryst. Growth 197, 475 (1999).

8. N.K. Morozova, I.A. Karetnikov, V.V. Blinov, E.M. Gavrishchuk. A study of luminescence centers related to copper and oxygen in ZnSe. Semiconductors 35 (1) 24 (2001).

9. N.K. Morozova, I.A. Karetnikov, V.V. Blinov, E.M. Gavrishchuk. Studies of the infrared luminescence of $\mathrm{ZnSe}$ doped with copper and oxygen. Semiconductors 35 (5) 512 (2001).

10. K.K. Rebane. Elementary Theory of the Vibrational Structure of Spectra of Admixture Centers in Crystals (Nauka, 1968) (in Russian).

11. A.F. Lubchenko. Quantum Transitions in Admixture Centers in Solids (Naukova Dumka, 1978) (in Russian).

12. V.E. Lashkarev, A.V. Lyubchenko, M. Sheinkman. Nonequilibrium Processes in Photoconductors (Naukova Dumka, 1981) (in Russian).

13. I.Ya. Gorodetskii, K.K. Dubenskii, V.E. Lashkarev et al. Determination of parameters of recombination centers in ZnSe monocrystals. Fiz. Tekhn. Polupr. 1 (11), 1666 (1967). 
14. V.Ya. Degoda, N.Yu. Pavlova, G.P. Podust, A.O. Sofiienko. Spectral structure of the X-ray stimulated phosphorescence of monocrystalline ZnSe. Physica B: Condensed Matter. 465, 1 (2015).

15. M. Alizadeh, V.Ya. Degoda, B.V. Kozhushko, N.Yu. Pavlova. Luminescence of dipole-centers in ZnSe crystals. Functional Materials 24 (2), 206 (2017).

Received 05.03.18

М. Алізадех, В.Я. Дегода

СПЕКТРИ РЕНТГЕНІВСЬКОГО

I ФОТОЛЮМІНЕСЦЕНЦІї

ВИСОКООМНИХ КРИСТАЛІВ ZnSe

$\mathrm{P}$ е 3 ю м е

Спектри люмінесценції високоомних кристалів ZnSe складаються з двох основних смуг з максимумами при $630 \mathrm{Hм}$
(1,92 еВ) і 970 нм (1,28 еВ). Проведено порівняння спектрів рентгенолюмінесценції і фотолюмінесценції ZnSe між собою в спектральної області від 400 до 1200 нм при різних інтенсивностях збудження і при різних температурах $(8,85,295$ i 420 K). Встановлено, що форми смуг свічення не залежать від інтенсивностей збудження. Форма смуги з максимумом при 970 нм також не залежить від типу збудження, а смуга 630 нм - трохи відрізняється при рентгенівському і УФзбудженні. Проаналізовано температурні спектральні положення максимумів смуг і їх півширини. Зроблено висновок про елементарності смуги світіння 970 нм. Короткохвильове зміщення спектрального максимуму смуги 630 нм при збільшенні температури дозволяє зробити висновок про неелементарність цієї смуги світіння. Це корелює з раніше виявленою особливістю цієі смуги про реалізацію двох механізмів рекомбінації (електронному та дірковому) на цьому центрі світіння. 